\title{
A Comparative Analysis of Training Method Convergence vs. Divergence in East Asia
}

\author{
Charles M. Vance (Corresponding Author) \\ Loyola Marymount University, Los Angeles, CA 90045 \\ Email: cvance@1mu.edu \\ Irene Hau-siu Chow \\ Hang Seng Management College, Hang Shin Link, Siu Lek Yuen \\ Shatin, N.T., Hong Kong \\ Email: irenechow@hsmc.edu.hk \\ Yongsun Paik \\ Loyola Marymount University, Los Angeles, CA 90045 \\ Email:yspaik@1mu.edu \\ Jeffrey Gale \\ Loyola Marymount University, Los Angeles, CA \\ Email: jgale@1mu.edu
}

Doi:10.5296/ijld.v5i1.7334ＵRL: http://dx.doi.org/10.5296/ijld.v5i1.7334

\begin{abstract}
This exploratory study examined the nature of convergence versus divergence among perceptions of 440 host country national employees in Thailand, Hong Kong, and PRC China related to widely recognized methods for conducting workforce training. Results revealed differences among five resulting major training method factors. In addition, the Hong Kong and PRC samples showed a more similar pattern, suggesting that shared Chinese ethnicity can have a stronger influence on perceptions of effective training practice than the pull toward convergence from globalization and exposure to Western practices. These results discourage assumptions of universal training method applicability and homogeneity among East Asian countries.
\end{abstract}

Key Words: International Human Resources, Cultural Convergence vs. Divergence, Host Country Workforce Training

\section{INTRODUCTION}

An ongoing shift in global economic activity from developed to developing economies, accompanied by growth in the number of consumers in emerging markets, are global developments that executives around the world view as the most important for business (Goldman Sachs, 2013; McKinsey Quarterly, 2010). In particular, the prospects of economic development and new business growth in countries within the Pacific Rim appear to be very positive. Foreign direct investment (FDI) will continue to increase in the form of cross-border mergers and acquisitions and the formation of business partnerships and alliances as multinational corporations 
(MNCs) compete for new and growing markets of both customers and employees. MNCs bring capital, technology, management skills, and the prospect of better corporate governance to these developing countries. Now as the world's $2^{\text {nd }}$ largest economy (Dickie, 2011), China has remained the largest recipient of FDI among the developing economies. These figures underscore the emergence of China as a new super economic power, which is the largest exporter and the largest trading nation in the world, as well as now the biggest automotive market.

Nevertheless, there are significant challenges ahead, and key to the success of MNCs that open operations in China and other Pacific Rim host countries will be their ability to recruit, train, and fully utilize their host country national workforce talent (Preece, Iles, \& Jones, 2013; Nankervis, 2013; Economist, 2010). With market-based reforms bringing new opportunities and challenges, the role played by employee training and development is becoming increasingly more compelling (Ashar et al., 2013; Levy, 2003). In China in particular, an increasing level of foreign investment, the radical restructuring of state-owned enterprises, and the rapid expansion of the private sector create a huge demand for a quality workforce at all levels (Cheng \& Waldenberger, 2013; Wang, Rothwell \& Sun, 2009). The training of workforce talent is essential to increase China's productivity in an era of accelerating global competition. A well-trained, educated, hardworking and conscientious labor force is regarded as a major contributor to the remarkable economic performance records of the Asia Tigers, i.e., Korea, Singapore, Taiwan and Hong Kong (Cooke, 2005). Yet China's huge labor force still largely lacks technical, managerial, and other skills required in a competitive global business environment (Sheldon \& Li, 2013). MNCs like Motorola, Ericsson, and Siemens have set up their own corporate universities and training centers in China to help meet the tremendous demand for a quality workforce. Building greater skills among Chinese employees and managers in problem solving, creativity, supervision, and strategic thinking has been identified by several sources as critical for both Western and Chinese enterprises that desire to continue successful growth and competitive viability in our global marketplace (Vance \& Paik, 2011; Alon \& McIntyre, 2005).

Although there has been considerable research reported in the international business literature examining the preparation, training, and international assignment needs of MNC home country expatriates (typically Western) for foreign assignment success, comparatively little attention has been paid to the particular needs of members of the host country local labor force who largely staff those foreign operations (Vance, Vaiman \& Andersen, 2009; Toh \& Denisi, 2003, 2005; Aycan \& Kanungu, 1997). In particular, there still remains a great need for advancing both theory and practice for training employees of differing national cultures and backgrounds located in the various foreign country operations of an MNC (Varner \& Palmer, 2002; McLean \& Shi, 2000). This new direction departs significantly from traditional research in international human resource that almost exclusively focuses on the training and support needs of Western expatriates relative to their foreign assignment (e.g., Mendenhall et al., 2008; Stroh et al., 2004) - at the neglect of the host country workforce with whom they have significant interactions. With the increasing costs and difficulties associated with expatriate assignments, many believe there is now a need for a major shift to the training and development of HCNs for carrying out multinational organizations' strategic objectives (Vance, Vaiman \& Andersen, 2009; Reiche, 2006; Harvey \& Fong, 2000).

Reflecting an ethnocentric bias, the Western literature has not demonstrated a clear recognition for the necessity of adapting training approaches and techniques to fit possibly differing learner needs of different countries and cross-cultural conditions (Vance \& Ensher; 2002; Vance \& Ring, 1994). The nearly automatic transfer abroad of Western methods of training and management education, with little attention to the specific need for cultural adaptation, appears to 
assume a global convergence upon common "universal" principles of effective training and adult learning (Vance et al., 2005; Drost et al., 2002; McLean \& Shi, 2000). However, such an assumption of universal application of human resource management practices, including those involving employee training, has been found to be faulty (Paik, Zhuplev \& Vance, 2002; Vance \& Paik, 2002; Paik, Vance \& Stage, 2000; Hofstede, 1993).

The convergence perspective in international management predicts that as we become a more interdependent global economy, we continue to achieve convergence upon rather generalizable, common principles and approaches for managing organizations (Woldu \& Budhwar, 2006; Von Glinow, Drost \& Teagarden, 2002; Rowley \& Benson, 2002), which would include the design and management of training in organizations. According to this view, a greater convergence toward norms of Western practices would be expected for FDI destinations such as Hong Kong and Thailand that have had relatively more exposure to Western principles of management than experienced by other countries such as China. However, the competing divergence perspective suggests that there are very persistent cultural differences that still remain and significantly influence performance in organizations (Beugelsdijk, Van Schaik \& Arts, 2006; Mayrhofer \& Brewster, 2005; Huo, Huang \& Napier, 2002; Jackson, 2002). Although in following a convergence perspective our long-term expectation for foreign operations might be

the application of universally-recognized "world class" or state-of-the-art principles and approaches for the management of training and individual learning, a divergence perspective would warn against neglecting enduring and important culturally-based differences.

The purpose of this exploratory study in is to extend beyond the traditional focus in international training on MNC home country expatriates, and to examine the impact of convergence versus divergence among host country nationals in Thailand, Hong Kong, and China related to widely recognized Western methods for conducting workforce training. Given the strong differential impact of culture on organizational behavior and management practices (McGuire et al., 2002; Adler, Doktor, \& Redding, 1986), it may be possible to identify culturally-based employee differences among these different countries for which widely accepted "universal" training practices may not be completely appropriate. Particularly in China where continued FDI growth is projected, an awareness of the degree of transferability of widely-recognized traditional Western training principles underlying training design and delivery would be important for MNC decision makers as they plan for optimal local employee preparation, training, and utilization. In addition, this research may be valuable in pointing to new, more applied research directions for prescribing specific training guidelines and practices appropriate for workplace talent in China, Thailand, and Hong Kong.

\section{Traditional Principles of Effective Training: Convergence vs. Divergence}

Considerable research, primarily reflected in Western literature, has been conducted to identify and disseminate training practices that lead to optimal learning on the part of an organization's human talent (Roszkowski, \& Soven, 2010; Denby, 2010; Garavan et al., 2010; Minear \& Shah, 2008; Velada et al., 2007). These approaches frequently are based on such general principles as employee perceptions of both training relevance and its value or instrumentality for future success, the desirability of learner control over the learning process,

the need for effective use of feedback, and the value of a learning climate that is friendly and supportive. Each of these major principles underlying effective training, which often are followed with assumed universal applicability, will now be examined briefly, followed by implications regarding their possible applicability (convergence) or need for adaptation (divergence) for the effective implementation of training practices in foreign operations in Thailand, Hong Kong, and China. 
Relevance of training. There is considerable evidence that trainees are motivated to attend to and participate in their training when they perceive training content and activities to be relevant to what they will face in the workplace (Bhatti \& Kaur, 2010; Roszkowski \& Soven, 2010; Kodwani \& Singh, 2004; Vermeulen, 2002). Related to this principle of training relevance is the utilization of practice that simulates what the employees will use on the job, as well as general work performance-based training strategies (Swee, 2002; Brethower \& Smalley, 1998).

Instrumentality of training to future success. Related to relevance of training is the principle of perceived instrumentality. Trainees' motivation to participate and succeed, as well as actual performance improvement, have been found to be associated with perceptions that the training will benefit the employee's immediate job performance, contribute to future individual career success, and improved organizational performance and achievement (Walker \& Greene, 2009; Guerrero \& Sire, 2001; Simons, DeWitte \& Lens, 2000).

Learner control. According to this principle, trainees as adult learners generally have a deep psychological need for self-regulated learning, and prefer to take responsibility for their own lives and to be self-directed. When they find themselves in situations where they feel others are making decisions for them, including in formal training or other learning situations, they may feel resentment and resist in the learning process. When these learners take greater control and personal responsibility in the learning process, they tend to learn and retain more, and do so more efficiently (Kraiger \& Jerden, 2007; Scheiter \& Gerjets, 2007; Azevedo \& Cromley, 2004; Schmidt \& Ford, 2003; Knowles, 1984).

Effective use of feedback. Here an individual's learning performance is given regular and timely feedback. It is frequent enough to allow for immediate information to help confirm the appropriateness of, or if inappropriate, correct one's specific performance. The feedback also emphasizes the use of positive reinforcement, such as praise and recognition, which provides a source of more powerful and enduring intrinsic motivation for the learner (Rantz et al., 2009; El-Masry, 2009; Gaumond, 2007; Roscoe et al., 2006).

Supportive and friendly climate. According to this principle, trainers should attempt to build a climate of friendliness, trust, and support; not one of competitiveness, distrust, and threat. Mistakes and errors are perceived as opportunities for learning, both through direct experience and vicarious learning through the shared and observed behaviors and experiences of others. Here high quality and open interpersonal relationships, both between trainer and individual learner and among the trainees themselves, are very important in providing support conducive to learning and personal growth (Carter \& Beier, 2010; Keith \& Frese, 2008; Papmehl, 2004; Knowles, 1984).

\section{Effective International Training Practice: Convergence vs. Divergence}

If a convergence effect is strong, it will tend to render HCN employees' value-based perceptions in line with traditionally prescribed principles of effective training, and thus little cultural customization would be needed to fit local workforce training needs. As suggested earlier, a convergence effect would be expected where non-Western HCN employees have had significant experience and interaction with Western culture, employees, and management practices, including those practices related to employee training. This significant exposure would widen value-based perceptual differences between these $\mathrm{HCN}$ employees and those with much more limited exposure to the West. For example, forms of convergence in managerial work values were found among managers in Russia, Japan, China, and the United States due to exposure to common economic ideologies underlying globalization (Ralston et al., 1997). Woldu, Budhwar \& Parkes (2006) found evidence of convergence in cultural value orientations among Polish, Russian, Indian, and US employees who shared the common industrial environments of professional and technical organizations. Tan (2002) also found evidence that their greater experience with industrialization 
and modernization made the personal value systems of Singaporean Chinese managers more similar to those of American Chinese managers than to Chinese managers in the PRC. We therefore would expect that with their more extensive history and experience with Western culture and management practices, when compared with Chinese workers, HCN employees in both Thailand and Hong Kong would reflect greater convergence toward or agreement with traditional widely-accepted Western training principles. We thus present hypotheses 1 and 2:

H1: Thai employees will reflect greater agreement on the importance of traditional Western principles guiding employee training than their employee counterparts in mainland China.

H2: Hong Kong employees will reflect greater agreement on the importance of traditional Western principles guiding employee training than their employee counterparts in mainland China.

Recent research has demonstrated that even among countries with significant experience with Western business and management practices, a divergence effect of culture is still evident, requiring customization, especially associated with local preferences for particular supervisory styles and human resource practices, including staffing, performance appraisal, compensation, and training (Lui, Lau \& Ngo, 2004; Vance \& Paik, 2002; Paik, Vance \& Stage, 2000). Therefore, based on the rather large cultural distance between the West and the Southeast Asian cultures of Thailand, Hong Kong, and China, we alternatively predict the following third hypothesis:

H3: The perceptions of host country national employees in Thailand, Hong Kong, and China regarding the importance of various approaches to employee training will markedly differ from widely recognized training principles generated from Western research.

In addition, based on the above described persisting divergence effect, we would predict that Hong Kong employees, despite the historically significant interactions and experiences with Western business and management practices, would reflect culturally based preferences for workplace practices that are more like those held by their ethnic counterparts in China. More specifically, we propose the following fourth hypothesis:

H4: PRC Chinese and Hong Kong employees will reflect significant agreement regarding the importance of various training method practices, and will differ in their perceptions of those practices from Thai employees.

\section{METHOD}

\section{Measure}

Based on a review of the literature on effective training methods and input from an expert panel of 9 professional corporate trainers in Southern California with a minimum of 10 years of experience, a general survey assessing respondent perceptions was developed containing 43 different behavioral approaches and characteristics for conducting employee training (each of the 43 items was measured by a seven-point, 1-7, bi-polar rating scale, 1=Not Important, 7=Extremely Important). The focus of the item measures was limited to the actual conduct of the training, rather than upon pre-training preparation and post-training measures aimed at maximizing learning transfer to the job. This survey was pilot tested with a group of 23 working MBA students at a private university in Southern California to determine whether each item was clear and able to achieve adequate variation in responses. Based on this pilot test, slight revisions were made for clarity, resulting in the final version of the survey. 
English-speaking nationals from Thailand and Hong Kong (also fluent in their own country language) translated the survey into their own language, and then a national colleague translated the survey back into English to ensure equivalence of meaning of each item. Although the survey participants in Hong Kong spoke Cantonese, the translated survey characters would have the same meaning for the survey participants in the PRC even though they spoke Mandarin. Nevertheless, the Chinese version of the survey translated in Hong Kong was back-translated by English-fluent Mandarin-speaking Chinese in the PRC to ensure accuracy of translation and meaning equivalence.

\section{Sample and Procedures}

The final form of the survey was distributed by the researchers using a convenience sampling method through direct company contacts made in Bangkok, Hong Kong, and three major cities in Eastern China. The present study focused on operations level employees below the level of supervisor in assembly and light manufacturing plants. The questionnaires were distributed to the respondents through each company's internal distribution system. All completed questionnaires were returned directly back to the researchers by prepaid stamped envelope. The sample consisted of 440 full-time non-managerial employees from 16 firms in three Asian countries (209 from Hong Kong, 129 from PRC China, and 102 from Thailand). The size of the subsidiaries varied greatly, with the number of employees ranging from 37 to 15,000, and with an average of 2,913. The average age of the respondents was 31.2, with 9.5 years of work experience, and 5.76 years with the current employer. $56.7 \%$ of the respondents were female. $68.2 \%$ had previously participated in training provided by their present company and $58.7 \%$ had participated in company training provided by a previous employer. The characteristics of the sub-samples are given in Table 1.

Insert Table 1 about here

\section{RESULTS}

Factor analysis of the original 43 items using varimax rotation resulted in five factors containing a total of 30 items, explaining a total of $58 \%$ of the variance and providing general support for the previously-described general Western principles and practices for conducting training (refer to Table 2). The alpha coefficient of each detected factor was relatively high, demonstrating an acceptable level of reliability of measures used in this study. The first factor, Perceived Relevance and Instrumentality, consisted of 9 items with an alpha of .89. An example measure includes "Training methods and learning activities are realistic to the problems and challenges faced at work." The second factor, Supportive and Friendly Climate, included 7 items with an alpha of .84. An example item is "Trainees are aware of top management support for the training that they are currently receiving." There were six items in the third factor, Learner Control, with alpha coefficient .84. An example is "Trainees have influence on the content of the training program." The fourth factor, Rich and Open Information Flow, included 6 items with an alpha of .76. An example is "Frequent feedback is provided to trainees on their learning progress." The last factor, Trait-Treatment Interaction, consisted of two items with an alpha coefficient of .62, and emphasizing training customization to fit trainee needs. An example is "The training is organized to build upon the skills and knowledge that the trainees already possess." The Five training indices were calculated by taking the mean value of the items in each factor. 
Insert Table 2 about here

Table 3 displays the correlations among variables. All five training factors are highly correlated among each other. These factors form a cohesive set of effective core training principles. An analysis of the factors with respondent demographics found that gender correlates only with Learner Control, while age and years of work experience are negatively correlated with all five factors. The older and more experienced employees perceived these training principles to be less effective. On the other hand, participation in training provided by both current and previous employers shows significant positive correlation with these training factors. Previous participation has significant positive effect on the perception of effective training practices.

Insert Table 3 about here

Evidence of cultural convergence relative to perceptions about training approach appropriateness was tested using ONEWAY analysis of variance. Hypothesis 1 states that Thai employees will reflect greater agreement with traditional Western principles guiding employee training than their counterparts in China. It is assumed that a higher score on these training method measures reflects greater agreement with traditional Western principles. This hypothesis is supported in all of the factors except factor 2 (support and friendly atmosphere), as indicated in Table 4. The research results show that Thai employees score significantly higher than PRC employees in general areas of perceived relevance and instrumentality, learner control, rich and open information flow, and trait-treatment interaction.

Insert Table 4 about here

Hypothesis 2 states that Hong Kong employees will reflect a convergence effect through greater agreement with traditional Western principles guiding employee training than their employee counterparts in mainland China. This hypothesis generally was not supported, with Hong Kong and China employees sharing similar perceptions on 4 out of 5 training factors. The exception was on the factor of rich and open information flow. This exception is consistent with Hong Kong's reputation as being a leading open market economy, far more transparent than mainland China (Kohli, 2007). And relative to PRC Chinese employees, employees in Hong Kong have much easier access to information in both their work environment and general society.

Hypothesis 3 tests for evidence of a divergence in perception of the widely-recognized training principles and practices generated from Western research. Results from a ONEWAY analysis of variance show highly significant differences among these three sample groups, except regarding supportive and friendly training environment (see Table 4). The importance of the training methods is perceived quite differently by the employees in the sample groups, supporting the divergence perspective.

Pair-wise comparisons of the sample groups show greater agreement among Hong Kong and PRC employees regarding the importance of various training method practices than their Thai counterparts, as indicated in post-hoc Scheffe results in Table 4. Thai employees have significantly higher scores than the two Chinese samples in four out of five training factors. Thus, Hypothesis 4 
is generally supported, giving evidence of a stronger divergence influence based on common Chinese ethnicity, despite national difference, that also greatly overshadows the convergence pull effect of globalization and Western influence as represented by the traditional Western traditional training principles.

DISCUSSION

The results of this exploratory study provide generally strong support for a divergence perspective in planning for training in different international contexts. Our results are particularly important for MNCs whose executives may falsely assume (1) undue homogeneity among Asian countries, and East Asia in particular, and (2) that principles guiding the management of training in their own Western parent country also would be appropriate for other countries, including those of East Asia.

On four out of five factors, our three country samples differed significantly. In particular, we found evidence of a persistent divergence effect among employees in our Thailand and PRC sample. The Hong Kong and PRC samples showed a more similar pattern, while the Thailand sample scored higher than the other two Chinese groups on all the training factor dimensions, suggesting that shared Chinese ethnicity can have a stronger influence on perceptions of effective training practice than the pull toward convergence from forces of globalization and significant exposure to Western practices. Despite the century-long ruling of the British, this finding of Hong Kong-PRC similarity may be a testimony that many values and norms of Hong Kong Chinese have not changed much. Or it is possible that this result may indicate that the values and norms of Hong Kong Chinese have greatly been influenced by those of mainland Chinese since its return to China in 1997. Whatever interpretation might be, it is rather surprising that Thailand received higher scores in agreement with Western training principles than Hong Kong in each of the five training dimensions despite the fact that Hong Kong has been one of the major offshore banking centers for Western MNCs, and thus has been more exposed to Western influence, including training methods of Western companies.

The fifth factor in the five-factor structure identified in our study, Trait-Treatment Interaction, emphasizes the importance of customization of training to meet the unique needs and conditions of trainees (Santally \& Alain, 2006; Buch \& Bartley, 2002). This factor is particularly compatible with and responsive to a divergence perspective in international management. Besides other demographic and contextual variables, trainee cultural background and potential influence of national culture on perceptions of both training content and process would be relevant factors to consider for designing training that fits learner needs. Apart from an awareness of general cultural trends held by a particular host country labor force, Vance and Ensher (2002) have argued for the utilization of the voice of the intended host country workforce members themselves (either directly through interviews or indirectly through cultural perception diagnostic surveys) to ensure optimal customization of $\mathrm{HCN}$ employee training.

We found it interesting that all three national samples did not differ and reflected relatively high average scores on the factor of supportive and friendly climate, approaching the Western-based prescription. This result is consistent with analyses of all three cultures that have identified strong values of support and interpersonal/social harmony due to Buddhist and Confucian traditions (Yan \& Hunt, 2005; Ghauri \& Fang, 2001; Chuaprapaisilp, 1997). Our results also found that both Hong Kong and PRC employees expressed relatively low preference for the factor of learner control. Mean responses for these employees suggest that in general there would not be strong, conducive trainee expectations for self-direction (learner control over the learning process). This finding supports reported experiences of educators and trainers of Chinese students and employees in Hong Kong and the PRC who found that attempts at facilitating a lively group 
discussion or group training exercise requiring active learner involvement, participation, and self-direction are often met with stiff, uncomfortable resistance (Watkins \& Biggs, 2001; Alon \& McIntyre, 2005). This resulting behavior might have to do with the prevailing Confucian values in China which emphasize an unequal relationship between trainers and trainees. According to the preaching of Confucius, trainees (i.e., students), are supposed to be obedient to trainers (i.e., teachers). An instructor-centered rather than student-centered learning process is more compatible to the virtue of Confucianism. It is of course possible for learners to adapt to the trainer's approaches, which may even be an appropriate ultimate goal to enhance their long-term development and lifelong learning, and perhaps broader career progression and involvement within an MNC. However, if cost-effective learning is to take place, the trainer may be further ahead in ultimately influencing desired learner behavior change by first gearing the training to where the trainees actually are at the start of training in terms of their entering abilities and expectations (Davy, 2006).

An important limitation of this study is the use of perceptual measures. Future research that examines the impact of various training methods on actual trainee learning and performance improvement is necessary to help validate the present findings. The use of these perceptual measures also can be very problematic in cross-cultural research such as the present study, where instrument items may be perceived in different ways by respondents from diverse cultural groups. For example, in this study the Thai sample has significantly higher factor scores than the two ethnic Chinese groups. This result may be due largely to the fact that ethnic Chinese respondents tend to avoid extreme ends of a scale and prefer mid-range responses (Adler, Campbell \& Laurent, 1989). Therefore future studies should examine and further test the psychometric properties of the instrument before performing additional cross-cultural comparisons.

We also caution that since the respondents' nationality was used as a proxy for their exposure to Western cultural values, this approach may have compromised the validity of the results, and future studies should consider and include more direct sample measures for degree of Western exposure. Also, we recognize that practical differences from the research results may not be as significant as the statistical differences we detected. Our results only point out particular country trends that should now be examined and tested further prior to deriving specific guidelines for training design within each country. In addition, further study should examine more deeply the cultural basis of their differences to determine more clearly their significance for training practice. Finally, our convenience sampling approach that is commonly used in international field research might have unintentionally introduced extraneous factors compromising the validity of our results, despite the appearance of strong representativeness among the three samples of their respective local labor populations. Nevertheless, especially as an exploratory study, we believe that our findings are meaningful in bringing attention to important divergent perspectives for guiding future research and practice regarding employee training in East Asia. In addition, we hope that this research will help increase attention in the international training and broader international management literature beyond the traditional focus on MNC home country expatriates to also include important MNC human talent located in foreign operations. 
References

2015, Vol. 5, No. 1

Adler, N. J., Campbell, N., \& Laurent, A. 1989. In search of appropriate methodology: From outside the People's Republic of China looking in. Journal of International Business Studies, 90 (1), 61-74.

Adler, N.J., Doktor, R., and Redding, S.G. 1986. From the Atlantic to the Pacific Century: Cross-Cultural management reviewed. Journal of Management, 12, 295-318.

Alon, I., and McIntyre, J.R. (eds.) 2005. Business and Management Education in China: Transition, Pedagogy and Training. London: World Scientific Publishing Co.

Ashar, M., Ghafoor, M., Munir, E., and Hafeez, S. 2013. The Impact of Perceptions of Training on Employee Commitment and Turnover Intention: Evidence from Pakistan. International Journal of Human Resource Studies, 3(1): 74-88.

Aycan, Z., and Kanungo, R.N. 1997. Current issues and future challenges in expatriate management. In D.M. Sunders and Z. Aycan, (Eds.), New Approaches to Employee Management, 245-260. Greenwich, CT: JAI Press.

Azevedo, R., and Cromley, J.G. 2004. Does training on self-regulated learning facilitate students' learning with hypermedia? Journal of Educational Psychology, 96(3): 523-536.

Beugelsdijk, S., Van Schaik, T., and Arts, W. 2006. Exploring regional differences in value patterns by economic development, cultural heritage and cultural shocks. Regional Studies, 40(3): 317-327.

Bhatti, M.A., and Kaur, S. 2010. The role of individual and training design factors on training transfer. Journal of European Industrial Training, 34(7), 656-672.

Brethower, D., and Smalley, K. 1998. Performance-Based Instruction: Linking Training to Business Results. San Francisco: Pfeiffer Publications.

Buch, K., and Bartley, S. 2002. Learning style and training delivery mode preference. Journal of Workplace Learning, 14(1): 5-10.

Carter, M., and Beier, M. 2010. The Effectiveness of Error Management Training With Working-Aged Adults. Personnel Psychology, 63(3), 641-675.

Cheng, Y., and Waldenberger, F. 2013. Does training affect individuals' turnover intention? Evidence from China. Journal of Chinese Human Resources Management, 4(1): 16-38.

Chuaprapaisilp, A. 1997. Thai Buddhist philosophy and the action research process. Educational Action Research, 5(2): 331-336.

Cooke, F. L. 2005. Vocational and Enterprise Training in China: Policy, Practice and Prospect. Journal of the Asia Pacific Economy, 10(1): 26-55.

Davy, C. 2006. Recipients: the key to information transfer. Knowledge Management Research and Practice, 4(1): 17-25.

Denby, S. 2010. The importance of training needs analysis. Industrial and Commercial Training, 42(3), 147-150.

Dickie, M. February 25, 2011. The price that must be paid for revolving door leadership. Financial Times, 1.

Drost, E.A., Frayne, A.C., Lowe, K.B., and Geringer, J.M. 2002. Benchmarking training and development practices: A multi-country comparative analysis. Human Resource Management, 41(1): 81-104.

Economist. September, 2010. Business: Even harder than it looks; Foreign investment in China. 396(8700): 81. 
El-Masry, E. 2009. Training accounting students on the prevention of budgetary slack and its impact on feedback-seeking behaviour. Training \& Management Development Methods, 23(2): 331-343.

Garavan, T., Carbery, R., O'Malley, G., and O'Donnell, D. 2010. Understanding participation in e-learning in organizations: a large-scale empirical study of employees. International Journal of Training \& Development, 14(3), 155-168.

Gaumond, J. 2007. 8 steps to effective training feedback. Canadian HR Reporter, 20(19): 24-25. Ghauri, P., and Fang, T. 2001. Negotiating with the Chinese: A Socio-Cultural Analysis. Journal of World Business, 36(3): 303-325.

Goldman Sachs. 2013. Focus on Growth Markets. Website: http://www.goldmansachs.com/ourthinking/focus-on/growth-markets/. Accessed November 1, 2013.

Guerrero, S., and Sire, B. 2001. Motivation to train from the workers' perspective: example of French companies. International Journal of Human Resource Management, 12(6): 988-1004.

Harvey, M., and Fong, H. 2000. Inpatriate managers: The Need for realistic relocation reviews. International Journal of Management, 17(2): 151-159.

Hofstede, G. 1993. Cultural constraints in management theories. Academy of Management Executive. 7(1): 81-94.

Huo, P., Huang, J., Napier, N.K. 2002. Divergence or convergence: A cross-national comparison of personnel selection practices. Human Resource Management, 41(1): 31-44.

Jackson, T. 2002. The management of people across cultures: Valuing people differently. Human Resource Management, 41(4): 455-475.

Keith, N., and Frese, M. 2008. Effectiveness of error management training: A meta-analysis. Journal of Applied Psychology, 93: 59-69.

Knowles, M.S. 1984. The Adult Learner: A Neglected Species ( $3^{\text {rd }}$ edition). Houston, TX: Gulf.

Kodwani, A.D., and Singh, M. 2004. Towards Effective Training and Development in Indian Public Sector Enterprises: A Case-based Analysis. South Asian Journal of Management, 11(3): 36-56.

Kohli, U. 2007. Terms-of-Trade Changes, Real GDP, and Real Value Added in the Open Economy: Reassessing Hong Kong's Growth Performance. Asia-Pacific Journal of Accounting \& Economics, 4(2): 87-109.

Kraiger, K,. and Jerden, E. 2007. A New Look at Learner Control: Meta-analytic Results and Directions for Future Research, in S. M. Fiore and E. Salas (eds), Towards a Science of Distributed Learning, 65-90 (Washington, DC: American Psychological Association).

Levy, J. 2003. The next China revolution. Training \& Development, 57(5): 58-65.

Lui, S.S., Lau, C., and Ngo, H. 2004. Global convergence, human resources best practices, and firm performance: A paradox. Management International Review, 44: 67-86.

Mayrhofer, W., and Brewster, C. 2005. European HRM: Researching developments over time. Management Review, 16(1): 36-62.

McGuire, D., Garavan, T.N., Saha, S.K., and Murphy, J. 2002. The cultural boundedness of theory and practice in HRD? Cross Cultural Management, 9(2): 25-44.

McKinsey Quarterly. May 2010. Five Forces Reshaping the Global Economy: McKinsey Global Survey Results. Retrieved on 
http://www.mckinseyquarterly.com/Five_forces_reshaping_the_global_economy_McKin sey_Global_Survey_results_2581, February 26, 2011.

McLean, G.N., and Shi, C. 2000. The status of training and development in U.S.-People's Republic of China joint ventures. Journal of Transnational Management Development, 5(4): 41-56.

Mendenhall, M.E., Osland, J.S., Bird, A., Oddou, G.R., and Maznevski, M. 2008. Global Leadership: Research, Practice and Development. London: Routledge.

Minear, M., and Shah, P. 2008. Training and transfer effects in task switching. Memory \& Cognition, 36(8), 1470-83.

Nankervis, A.R. 2013. Building for the Future? Government and Industry Responses to the Challenges of Talent Management in China Following the GFC. Asia Pacific Business Review, 19(2): 186-199.

Paik, Y., Zhuplev, A. \& Vance, C.M. 2002. Comparing US and Russian management style: The influence of cultures on cooperative business ventures. International Journal of Human Resource Development, 2(3/4): 379-393.

Paik, Y., Vance, C.M., and Stage, H.D. 2000. A test of assumed cluster homogeneity for performance appraisal management in South East Asian countries. International Journal of Human Resource Management, 11(4): 736-750.

Papmehl, A. 2004. Culture change and organic growth. CMA Management, 78(6): 16-18.

Preece, D., Iles, P., and Jones, R. 2013. MNE Regional Head Offices and their Affiliates: Talent Management Practices and Challenges in the Asia Pacific. The International Journal of Human Resource Management, 24(18): 3457-3477.

Ralston, D.A., Holt, D.H., Terpstra, R.H., and Kai-Cheng, Y. 1997. The impact of national culture and economic ideology on managerial work values: A study of the United States, Russia, Japan, and China. Journal of International Business Studies, 28: 177-207.

Rantz, W., Dickinson, A., Sinclair, G., and Van Houten, R. 2009. The Effect of Feedback on The Accuracy of Checklist Completion During Instrument Flight Training. Journal of Applied Behavior Analysis, 42(3), 497-509.

Reiche, B.S. 2006. The Inpatriate Experience in Multinational Corporations: An Exploratory

Case Study in Germany. International Journal of Human Resource Management, 17(9): 1572-1590.

Roscoe, E.M., Fisher, W.W., Glover, A.C., and Volkert, V.M. 2006. Evaluating the Relative Effects of Feedback and Contingent Money for Staff Training of Stimulus Preference Assessments. Journal of Applied Behavior Analysis, 39(1): 63-77.

Roszkowski, M., \& Soven, M.. (2010). Did you learn something useful today? An analysis of how perceived utility relates to perceived learning and their predictiveness of satisfaction with training. Performance Improvement Quarterly, 23(2), 71.

Rowley, C., and Benson, J. 2002. Convergence and divergence in Asian human resource management. California Management Review. 44(2): 90-109.

Santally, M.I., and Alain, S. 2006. Personalization in web-based learning environments. International Journal of Distance Education Technologies, 4(4): 15-37.

Scheiter, K. and Gerjets, P. 2007. Learner control in hypermedia environments. Educational Psychological Review, 19: 285-307.

Schmidt, A.M., and Ford, J.K. 2003. Learning Within a Learner Control Training Environment:

The Interactive Effects of Goal Orientation and Metacognitive Instruction on Learning

Outcomes. Personnel Psychology, 56(2): 405-429.

Sheldon, P., and Li, Y. 2013. Localized Poaching and Skills Shortages of Manufacturing 
Employees among MNEs in China. Journal of World Business, 48(2): 186-195.

Simons, J., DeWitte, S., and Lens, W. 2000. Wanting to have vs. wanting to be: The effect of perceived instrumentality on goal orientation. British Journal of Psychology, 91: 335- 352.

Stroh, L.K., Black, J.S., Mendenhall, M.E., and Gregersen, H.B. 2004. International Assignments: An Integration of Strategy, Research, and Practice. London: CRC Press.

Swee, C.G. 2002. Managing effective knowledge transfer: An integrative framework and some practice implications. Journal of Knowledge Management, 6(1): 23-30.

Tan, B.L.B. 2002. Researching managerial values: A cross-cultural comparison. Journal of Business Research, 55(10): 815-821.

Toh, S.M., and DeNisi, A. S. 2005. A local perspective to expatriate success, Academy of Management Executive, 19(1): 132-146.

Toh, S.M., and Denisi, A.S. 2003. Host country national reactions to expatriate pay policies: A model and implications. Academy of Management Review, 28(4): 606-621.

Vance, C.M., and Paik, Y. 2011. Managing a Global Workforce: Challenges and Opportunities in International Human Resource Management ( $2^{\text {nd }}$ Ed.). Armonk, NY: M.E. Sharpe, Inc.

Vance, C., Vaiman, V., and Andersen, T. 2009. The vital liaison role of host country nationals in MNC knowledge management. Human Resource Management, 48(4), 649-659.

Vance, C.M., Boje, D.M., Stage, H.D., and Shah, A. 2005. Convergence or Divergence in International Training? An Analysis of Training Design Needs in Five Countries of the Pacific Rim. International Journal of Vocational Education and Training, 13(1), 75-92.

Vance, C.M., and Ring, P.S. 1994. Preparing the host country workforce for expatriate managers: The neglected other side of the coin. Human Resource Development Quarterly, 5(4): 337-352.

Vance, C.M., and Paik, Y. (2002) One Size Fits All in Expatriate Departure Training?: Comparing the Host Country Voices of Mexican, Indonesian, and US Workers. Journal of Management Development, 21(7), 557-571.

Vance, C.M., and Ensher, E.A. 2002. The voice of the host country workforce: A key source for improving the effectiveness of expatriate training and performance. International Journal of Intercultural Relations, 26(4): 447-461.

Varner, I.I., Palmer, T.M. 2002. Successful expatriation and organizational strategies. Review of Business, 23(2): 8-11.

Velada, R., Caetano, A., Michel, J.W., Lyons, B.D., and Kavanagh, M.J. 2007. The effects of training design, individual characteristics and work environment on transfer of training", International Journal of Training and Development, 11(4): 282-94.

Vermeulen, R.C.M. 2002. Narrowing the transfer gap: The advantages of "as if" situations in training. Journal of European Industrial Training, 26(8/9): 366-374.

Von Glinow, M.A., Drost, E.A., Teagarden, M.B. 2002. Converging on IHRM best practices: Lessons learned from a globally distributed consortium on theory and practice. Human Resource Management, 41(1): 123-140.

Walker, C.O., and Greene, B.A. 2009. The relations between student motivational beliefs and cognitive engagement in high school. The Journal of Educational Research, 102: 163-471.

Wang, G.G., Rothwell, W.J., and Sun, J.Y. 2009 Management Development in China: A Policy Analysis. International Journal of Training \& Development 13(4): 205-220. 
Watkins, D.A., and Biggs, J.B. (eds.) 2001. Teaching the Chinese Learner: Psychological and Pedagogical Perspectives. Hong Kong: Comparative Education Research Center, University of Hong Kong.

Woldu, H.G., Budhwar, P.S., and Parkes, C.A. 2006. A cross-national comparison of cultural value orientations of Indian, Polish, Russian, and American employees. International Journal of Human Resource Management, $17(6$ ): 1076-1094.

Yan, J., and Hunt, J.G. 2005. Femininity in Thailand and Chinese cultures: A cross cultural perspective on perceived leadership effectiveness. International Journal of Cross Cultural Management, (5)1: 49-66. 
Table 1

Sample Characteristics

\begin{tabular}{|l|l|l|l|}
\hline & Hong Kong & China & Thailand \\
\hline Sample size & 209 & 129 & 102 \\
\hline Female (\%) & 58.67 & 54.4 & 54.3 \\
\hline Average Age & 33.28 & 29.47 & 29.74 \\
\hline Years of work experience & 11.98 & 8.14 & 6.96 \\
\hline Organizational tenure (years) & 7.61 & 4.32 & 4.39 \\
\hline $\begin{array}{l}\text { Participated in training provided by } \\
\text { present co. (\%) }\end{array}$ & 73.1 & 54.84 & 76.29 \\
\hline $\begin{array}{l}\text { Participated in training provided by } \\
\text { previous co. (\%) }\end{array}$ & 62.09 & 47.79 & 65.26 \\
\hline
\end{tabular}


Table 2: Results of Factor Analysis

2015, Vol. 5, No. 1

\begin{tabular}{|c|c|c|c|c|c|}
\hline & \multicolumn{5}{|c|}{ Factor } \\
\hline & 1 & 2 & 3 & 4 & 5 \\
\hline \multicolumn{6}{|l|}{ Perceived Relevance and Instrumentality } \\
\hline $\begin{array}{l}\text { Training methods and learning activities are realistic to } \\
\text { the problems and challenges faced at work }\end{array}$ & .705 & .081 & .184 & .198 & -.185 \\
\hline $\begin{array}{l}\text { Trainees believe that the training will result in their work } \\
\text { performance improvement }\end{array}$ & .667 & .341 & .126 & .126 & -.012 \\
\hline $\begin{array}{l}\text { The trainer is an expert in facilitating learning among the } \\
\text { training participants }\end{array}$ & .587 & .067 & .098 & .336 & .178 \\
\hline $\begin{array}{l}\text { Trainees perceive that their training success will benefit } \\
\text { their future career }\end{array}$ & .621 & .282 & .193 & .055 & .277 \\
\hline $\begin{array}{l}\text { The training program includes application assignments } \\
\text { for use back at the workplace }\end{array}$ & .634 & .340 & .170 & .063 & .073 \\
\hline $\begin{array}{l}\text { Trainees feel personal responsibility for the success of } \\
\text { their learning in the training program }\end{array}$ & .622 & .195 & .266 & .112 & .234 \\
\hline $\begin{array}{l}\text { There is adequate opportunity during the training } \\
\text { program for practicing the skills or subject matter being } \\
\text { learned }\end{array}$ & .670 & .285 & .102 & .186 & .102 \\
\hline $\begin{array}{l}\text { A clear picture is presented to trainees about how the } \\
\text { training fits into the company's goals and objectives }\end{array}$ & .645 & .141 & .259 & .151 & .383 \\
\hline $\begin{array}{l}\text { The training includes realistic examples and problems } \\
\text { like those faced at work }\end{array}$ & .625 & .162 & $\begin{array}{l}-.01 \\
1\end{array}$ & .235 & .334 \\
\hline \multicolumn{6}{|l|}{ Supportive and Friendly Climate } \\
\hline $\begin{array}{l}\text { Mistakes and errors made during training are treated as } \\
\text { opportunities for learning, not as sources of } \\
\text { embarrassment }\end{array}$ & .392 & .477 & .127 & .314 & -.173 \\
\hline $\begin{array}{l}\text { There is a strong atmosphere of support among } \\
\text { participants during the training program }\end{array}$ & .379 & .590 & .226 & .259 & .116 \\
\hline $\begin{array}{l}\text { Trainees are aware of top management support for the } \\
\text { training that they are currently receiving }\end{array}$ & .322 & .547 & .162 & .028 & .325 \\
\hline The training experience is enjoyable & .116 & .700 & .060 & .207 & .133 \\
\hline $\begin{array}{l}\text { The training is perceived by trainees as beneficial to the } \\
\text { company }\end{array}$ & .367 & .575 & .366 & .021 & .127 \\
\hline $\begin{array}{l}\text { The training methods build confidence in trainees that } \\
\text { they can successfully learn the subject matter of the } \\
\text { training }\end{array}$ & .461 & .536 & .136 & .208 & .129 \\
\hline $\begin{array}{l}\text { A spirit of harmony and cooperation is encouraged } \\
\text { among participants in the training program }\end{array}$ & .206 & .725 & .194 & .062 & -.063 \\
\hline \multicolumn{6}{|l|}{ Learner Control } \\
\hline $\begin{array}{l}\text { Trainees have influence on the content of the training } \\
\text { program }\end{array}$ & .012 & .052 & .636 & .496 & .030 \\
\hline $\begin{array}{l}\text { Trainees have influence on the pace of the training } \\
\text { program }\end{array}$ & .047 & .166 & .642 & .277 & .137 \\
\hline $\begin{array}{l}\text { Competition is encouraged among individuals during the } \\
\text { training program }\end{array}$ & .226 & .112 & .804 & .022 & .009 \\
\hline
\end{tabular}




\section{$\Lambda$ Macrothink}

International Journal of Learning \& Development

ISSN 2164-4063

Competition is encouraged among teams during the training

The trainee has some influence on how the training program is conducted

Trainees have some degree of personal control over their own learning

Rich and Open Information Flow

The training program is clearly organized

Frequent feedback is provided to trainees on their learning progress

Individual trainees feel respected during the training program

Multiple training methods are used to address different learning styles among the trainees

The training is designed to maintain trainees attention

Trainees feel free to express their personal opinions

Trait-Treatment Interaction

The training is customized to fit the unique needs and circumstances of the trainees

The training is organized to build upon the skills and knowledge that the trainees already possess

$\%$ of variance explained 2015, Vol. 5, No. 1

\begin{tabular}{|l|l|l|l|l|l|} 
& .401 & .291 & $\mathbf{. 6 5 4}$ & -.080 & .016 \\
\hline ir & .159 & .226 & $\mathbf{. 6 8 8}$ & .190 & .200 \\
\hline .353 & .283 &. $\mathbf{4 3 7}$ & .255 & .185 \\
\hline & & & & \\
\hline .302 & .211 & -.14 & $\mathbf{. 6 1 3}$ & .055 \\
\hline .227 & -.07 & 3 & .266 & $\mathbf{. 6 5 1}$ & .133 \\
\hline-.029 & .321 & .164 & $\mathbf{. 6 0 5}$ & .260 \\
\hline .171 & .087 & .167 & $\mathbf{. 6 3 4}$ & .189 \\
\hline .389 & .127 & .125 & $\mathbf{. 5 5 3}$ & -.260 \\
\hline .110 & .327 & .271 & $\mathbf{. 4 7 5}$ & .010 \\
\hline & & & & \\
\hline .367 & .194 & .147 & .270 & $\mathbf{. 6 1 0}$ \\
\hline & .227 & .061 & .434 & .182 & $\mathbf{. 5 5 5}$ \\
\hline & & & & \\
\hline 18.0 & $\begin{array}{l}11.9 \\
3\end{array}$ & 11.8 & 10.6 & 5.47 \\
\hline
\end{tabular}




\section{Among Variables}

Table 3: Correlations

\begin{tabular}{|c|c|c|c|c|c|c|c|c|c|c|}
\hline & 1 & 2 & 3 & 4 & 5 & 6 & 7 & 8 & 9 & 10 \\
\hline $\begin{array}{l}\text { 1. Perceived Relevance } \\
\text { 2. Supportive Climate } \\
\text { 3. Learner Control } \\
\text { 4. Information Flow } \\
\text { 5. Trait-Treatment } \\
\text { 6. Gender } \\
\text { 7. Age }\end{array}$ & $\begin{array}{l}.72 * * * \\
.56 * * * \\
.55 * * * \\
.58 * * \\
.07 \\
-.16 * *\end{array}$ & $\begin{array}{l}.58 * * * \\
.53 * * * \\
.49 * * * \\
.08 \\
-.15 * *\end{array}$ & $\begin{array}{l}.52^{* * *} \\
.55^{* * *} \\
.10^{*} \\
-.16^{* *}\end{array}$ & $\begin{array}{l}.49 * * * \\
.07 \\
-.13 *\end{array}$ & $\begin{array}{l}.04 \\
-.11 *\end{array}$ & -.08 & & & & \\
\hline $\begin{array}{l}\text { 8. Years of work } \\
\text { experience }\end{array}$ & $-.16 * *$ & $-.12 *$ & $\begin{array}{l}-.17 * * \\
*\end{array}$ & $-.11 *$ & $-.14 * *$ & $-.11 *$ & $.89 * * *$ & & & \\
\hline $\begin{array}{l}\text { 9. Years with current } \\
\text { employer }\end{array}$ & -.10 & -.04 & -.03 & -.07 & -.08 & .01 & $.59 * * *$ & $.62 * * *$ & & \\
\hline $\begin{array}{l}\text { 10. Participated in training } \\
\text { provided present } \\
\text { company }\end{array}$ & $.17 * * *$ & $.18^{* * *} *$ & $.17 * * *$ & .04 & $.14 * *$ & -.03 & $-.21 * *$ & $\begin{array}{l}-.17 * * \\
*\end{array}$ & $-.16 * *$ & \\
\hline $\begin{array}{l}\text { 11. Participated in company } \\
\text { training provided by } \\
\text { previous employer }\end{array}$ & $.12 *$ & $.20 * * *$ & $.20 * * *$ & $.11^{*}$ & .04 & .07 & $-.23 * *$ & $\begin{array}{l}-.18^{* *} \\
*\end{array}$ & -.07 & $.39 * * *$ \\
\hline
\end{tabular}

Correlation is significant at the $* \quad \mathrm{p}<0.05 ; * * \mathrm{p}<0.01 ; * * * \mathrm{p}<.001$ level 
Table 4

Mean Differences on Effective Training among the Three Sample Groups

\begin{tabular}{|l|l|l|l|l|l|}
\hline & HK & $\begin{array}{l}\text { China } \\
(\mathrm{CN})\end{array}$ & $\begin{array}{l}\text { Thailand } \\
(\mathrm{THAI})\end{array}$ & $\begin{array}{l}\text { One-way } \\
\text { ANOVA F }\end{array}$ & $\begin{array}{l}\text { Post Hoc } \\
\text { Scheffe Test }\end{array}$ \\
\hline $\begin{array}{l}\text { Perceived Relevance } \\
\text { and Instrumentality }\end{array}$ & 5.53 & 5.72 & 6.00 & $11.61 * * *$ & $\begin{array}{l}\text { HK=CN } \\
\text { HK<THAI } \\
\text { CN<THAI }\end{array}$ \\
\hline $\begin{array}{l}\text { Supportive and } \\
\text { Friendly Climate }\end{array}$ & 5.66 & 5.72 & 5.68 & .22 & $\begin{array}{l}\text { HK=CN=TH } \\
\text { AI }\end{array}$ \\
\hline $\begin{array}{l}\text { Learner Control and Open } \\
\text { and }\end{array}$ & 5.78 & 4.71 & 5.29 & $11.03 * * *$ & $\begin{array}{l}\text { HK=CN } \\
\text { HK<THAI } \\
\text { CN<THAI }\end{array}$ \\
\hline $\begin{array}{l}\text { Rich Information Flow } \\
\text { Irait-Treatment }\end{array}$ & 5.51 & 5.30 & 5.80 & $11.80 * * *$ & $\begin{array}{l}\text { HK>CN } \\
\text { HK<THAI } \\
\text { CN<THAI }\end{array}$ \\
\hline $\begin{array}{l}\text { Interaction } \\
\text { HK }=\text { CN } \\
\text { HK<THAI } \\
\text { CN<THAI }\end{array}$ \\
\hline
\end{tabular}

$* * * \mathrm{p}<.001$ 